International Journal of English Literature and Social Sciences
Vol-6, Issue-6; Nov-Dec, 2021

Peer-Reviewed Journal

\title{
Indian Poetry and Oral Narratives during the First World War: A Subaltern response
}

\author{
Shuvabrata Basu
}

M. Phil Research Scholar, Department of English, Visva-Bharati University, West Bengal, India

Received: 19 Sep 2021; Received in revised form: 08 Nov 2021; Accepted: 16 Nov 2021; Available online: 24 Nov 2021

(C)2021 The Author(s). Published by Infogain Publication. This is an open access article under the CC BY license

(https://creativecommons.org/licenses/by/4.0/).

\begin{abstract}
First World War creates a kind of global impact all over the world. Almost all major countries joined in the battlefield and they shared their own experiences that were recorded as a saga of war history. India was no less an exception. During the First World War, the inhuman torture of the 'master' class and the war experiences of the British-Indian army have been shared either by their own voices or by the verse of many poets of undivided India through their own sense perceptions and "continuous overflow of powerful feelings". It was a major turn of global historiography in the world literature. The oral narratives of the soldiers may not be always the 'high literature' but they are highly literary in the sense of their shared memories of war and trauma. The semi-literate people from the villages of Asia, Africa or the South Pacific came voluntarily or involuntarily to save their mother India and what they left is oral saga rich in their own culture and language that is often fused to a variety of forms, from everyday prayers, chants and folk songs through verse recitations and storytelling. India as a multi-lingual, multi-ethnic and multi-religious country offers many prose and verse in vernacular languages that unveil the subaltern response to the Eurocentric attitude to war. In my article I have tried to investigate and unfurl the voices of the subaltern Indian soldiers and their families as well as the poems written by the multilingual poets from undivided India that reestablish an Indian war experience and the complex 'structures of feelings'.
\end{abstract}

Keywords - Subaltern, structures of feeling, memory and trauma, Eurocentric attitude, folk songs, oral literature.

The term 'Subaltern' designates and identifies the colonial populations who are socially, politically and geographically excluded from the hierarchy of power of an imperial colony and from the metropolitan homeland of an empire. According to M. H. Abrams, in his A Handbook of Literary Terms, the subaltern has become a standard way "to designate the colonial subject that has been constructed by European discourse and internalized by colonial peoples who employ this discourse" (Abrams, 2009, p. 238). Abrams continues that 'subaltern' is a British word for someone of inferior military rank, and combines the Latin terms for 'under' (sub) and 'other' (alter) (Abrams, 2009, p. 238).Antonio Gramsci coined the term 'subaltern' to identify the cultural hegemony that excludes and displaces specific people and social groups from the socio-economic institutions of society, in order to deny their agency and voices in colonial politics. In an interview Gayatri Chakravorty Spivak cautioned against an over-broad application of the term the subaltern, because the word: "subaltern is not just a classy word for 'oppressed', for [the] Other, for somebody who's not getting a piece of the pie ... In post-colonial terms, everything that has limited or no access to the cultural imperialism is subaltern - a space of difference. Now, who would say that's just the oppressed? The working class is oppressed. It's not subaltern ...Many people want to claim [the condition of] subalternity. They are the least interesting and the most dangerous. I mean, just by being a discriminated-against minority on the university campus; they don't need the word 'subaltern'.... They should see what the mechanics of the discrimination are. They're within the hegemonic discourse, wanting a piece of the pie, and not being 
allowed, so let them speak, use the hegemonic discourse. They should not call themselves subaltern" ("Subaltern (postcolonialism)", 2021).

According to Bill Ashcroft, in his influential book Post Colonial Studies: the Key Concepts, the term 'Subaltern' means 'of inferior rank' in society "who are subject to hegemony of the ruling classes" (Ashcroft et al., 2007, p. 198). Subalterns may include peasants, workers and other groups denied access to 'hegemonic' power. In 'Notes on Italian History' (1934-5), Gramsci claimed that the history of subaltern classes was as complex as the history of the dominant class. The history of the ruling class has still been considered as 'official' history. Modern historians utterly neglect the study of the British Indian army in the battlefield of First World War in France and Mesopotamia. Their stories have been doubly marginalized: first by the nationalist elitist historiography and secondly by the grand narrative of war. For Gramsci, the history of subaltern social groups is necessarily fragmented and episodic. They have less access to the means of controlling their own representation and also to their cultural and social institutions. In spite of domination and class conflict in the battlefield, the poets from undivided India penned for the voices of the peasant and semi-literate class.

The First World War (1914-1918) had a profound effect on Indian politics as well as Indian literature. In the Russo- Japanese War (1904-1905), Japanese victory over Russia acted as a catalyst in galvanizing the Asian notions against the hegemony of the European colonial power. Jawaharlal Nehru, in his autobiography captured the enthusiastic "Indian" feelings of those years: "Japanese victories stirred up my enthusiasm and I waited eagerly for papers for fresh news daily... Nationalistic ideas filled my mind. I mused of Indian freedom and Asiatic freedom from the thralldom of Europe" (Jalil, 2019, ix). South Asian victory thrust a ray of hope to the Indian to get rid of colonial dominion. In India extremist like Bal Gangadhar Tilak and Aurobindo Ghose began to challenge the existing Indian National Congress leadership with new ideology that combined Hindu revivalism and political activism. The Balkan Wars also had a great effect on Indian writers and poets. Just after the Balkan Wars, Lord Hardinge, the Viceroy of India declared that India as a colonial domain of the British had to participate in the Great War. The news of the war was ironically received enthusiastically by the then native princes and political bourgeoisie and educated middle class to show loyalty and support to the British.

India during the First World War witnessed the contribution of many poems. The urge and feeling of the poetic sensibility merged with the devotion to the battlefield. The poems, lost in the passage of time made important interventions during India's involvement to the First World War. The poems are not well-known today and these are not virtually available in websites but the poetic sensibility, as fragments and as a whole, create a "structures of feelings" that the youth and their family had experienced and felt during that time. Those momentary feelings got the shape of literariness in the hands of Indians. They are not all well-known established poets, nor do they have any fame world-wide internationally acclaimed. But these works are great documents to capture the feelings of that time. Their poetry was socially conscious and they bear the mark of political message during that time.

The strong yearning for freedom was evident in the Urdu poetry. Suroor Jahanabadi lamented in a poem called 'Khak-e-Watan' ('The Dust of the Homeland'):

Once your flag of greatness was flying high

Now the sign of your greatness lies in the dust.

Brij Narain Chakbast, in his poem also called 'Khak- e- Watan' said that hub-e-watan (love for the country) was no more though khak-e-watan (Dust of the country) remained the same. Zafar Ali Khan, in 'Mazaalim- e- Punjab' ('The Victims of Punjab'), mocked the British and the brutality of General Dwyer. In 'Sholae- Fanoos-e- Hind' ('The Spark in the Chandelier of Hind'), he went on to wish that all the drops of the martyrs' blood may be used to decorate the walls of the fort of freedom (qasr-e-azadi). Ehsan Danish in his anthem 'Tarana-e-Jihad' urged the Muslim community to go forth using the parameters of religion (Badhe chalo, badhe chalo). In a ghazal written in the year 1917, Mohani makes a passionate protest against the British capture of Baghdad in March 1917.

Famously known as the 'Nightingale of India', Sarojini Naidu (1879-1949) was a poet, freedom fighter and political leader. Born in Hyderabad, she was educated in Chennai, London and Cambridge. She was a part of the National movement, became a follower of Mahatma Gandhi, joined him in the famous Salt Satyagraha and fought for Swaraj. Naidu was named President of the Indian National Congress in 1925 and later appointed as the first Governor of the United provinces, now Uttar Pradesh. Her first collection of poems The Golden Threshold was published from London in 1905. She wrote poems on children, nature, patriotism, love and death.

An internationally celebrated poetess, Sarojini Naidu writes about Indian soldiers in her poem 'The Gift of India'. The poem is a tribute to the contribution of Indian soldiers in World War I. Over ten lakhs Indian 
soldiers from the British Indian Empire served in the Allied forces in the First World War. A vast number of them sacrificed their lives. Indian troops fought in different locations of significance to the allied stronghold and had an important share in many of the battles throughout the course of the war. However, the contribution of the Indian soldiers is overlooked in the vast expanse of the War's history. These selfless sacrifices of the Indian soldiers for the western agitation are captured in Naidu's poem 'The Gift of India'. The poem not only concentrates on the theme of soldiers making their ultimate sacrifice for someone else's war, but also talks about the numerous benefits the foreign countries reaped from India. The poet regards these benefits as gifts given by India to the colonisers. Naidu writes in her poem:

Gathered like pearls in their alien graves Silent they sleep by the Persian waves, Scattered like shells on Egyptian sands, They lie with pale brows and brave, broken hands, They are strewn like blossoms mown down by chance On the blood-brown meadows of Flanders and France.

And you honour the deeds of the deathless ones Remember the blood of thy martyred sons!

The lyric becomes distinctive as it is wrought in the hand of an Indian nationalist poet with Indian sentiment. The aestheticised vocabulary resembles Georgian poetry, and reveals the intimate processes of colonial education upon the Bengali middle class. The power of the poem is deeply rooted in the war-bereaved consciousness of a mother who fuses with the powerful trope of 'Mother India' suffering under colonialism. This poem is not a document for the death of the European bourgeois consciousness but a plea for the recognition of the Indian sepoys. It talks with eloquence and passion of the innumerable gifts India has contributed to Britain. Besides the' rich gifts of raiment or grain or gold' She has given her 'priceless treasures', Her sons who went on marching to 'the drum -beats of duty' who now alas sleep in forgotten graves. This image alludes to the poem 'Asleep in the Valley' by the French poet Arthur Rimbaud. Rimbaud also talks about the futility of war where young souls devoted their lives amidst the beautiful surroundings of Mother Nature:

A soldier, very young, lies open-mouthed, A pillow made of fern beneath his head, Asleep; stretched in the heavy undergrowth, Pale in his warm, green, sunsoaked bed.

One of the famous scholars of Sufism and literature Shibli Nomani (1857-1914) is a poet, teacher, and traveler. Nomani taught Persian and Arabic at the
M.A.O College in Aligarh for 16 years. Here he met British orientalist Thomas Arnold and other British scholars from whom he learnt at first-hand modern Western ideas and thoughts. He also travelled with Arnold to Syria, Egypt, Turkey and other Middle Eastern countries to experience their societies. Nomani wrote a two- volume biography of the Life of prophet Muhammad Sirat- un Nabi and set up the Shibli National College in 1883 and the Darul Mussanifin or House of Writers in Azamgarh.

In his wryly mocking 'Jang-e Europe aur Hindustani' ('The War in Europe and Indians'), he shows the other side of the coin:

Consumed with pride, a German said to me:

'Victory is not easy but it isn't impossible either

The army of Britannia is less than ten lakh

And not even prepared on top of that

As for France, they are a bunch of drunks

And not even familiar with the art of Warfare'

A warrant of arrest was issued against Shibli Naomi for writing this poem, however he died on 18 November 1914 before the warrant could be implemented.

Brij Narayan Chakbast (1882- 1926), born into a Kashmiri Pandit family in Awadh, was a British Indian Urdu poet. He is credited as being the exponent of a new style in Urdu poetry, which exerted a pure and sublime love for motherland. An active leader of Home Rule, he wrote several poems on the overarching theme of partition. In poems such as 'Khak-e-Watan', he rued the fact that hub-e-watan ('love for the country') was no more, though the khak-e-watan ('dust of the country') remained the same.

Inspired by the Irish Home Rule Movement of the late 19th and early 20th centuries, several nationalist leaders banded together in 1916 under the leadership of Annie Besant to voice a demand of self governance and obtain the status of a dominion within the British Empire as enjoyed by Australia, Canada, South Africa, New Zealand and Newfoundland at the time. While it enjoyed considerable popularity for some years, its growth and activity were stalled by the rise the Mahatma Gandhi, his Satyagraha and civil disobedience movement demanding complete independence.

The poem starts with:

The land of Hind is higher in rank than the highest skies

All because of the light of hope brought forth by Home Rule

This hope has been nurtured by Mrs Basant

I am a mendicant of this land and this is my song. 
It's futile to wish for the thorn instead of the flower

We shall not accept even Paradise instead of home rule.

The poem continues:

We shall bring the essays of patriotic Martyrs

And we shall wear it as Surma in our eyes

We shall bear all manner of hardship for our poor Mother

And we shall give the message of fidelity to the people.

Here, we can see the poet pay homage to the Martyrs of WW1. He respects the soil of Mother India as the brave souls once were born on this soil.

Another firebrand revolutionary Syed Fazl-ulHasan known by his pen-name Hasrat Mohani (1875-1951) was an ethical dissenter, maverick, romantic poet in the classical ghazal tradition, journalist, politician, parliamentarian and freedom fighter. He coined the notable slogan Inquilab Zindabad (translation of 'Long live the revolution!') in 1921(“Hasrat Mohani”, 2021). Together with Swami Kumaranand, he is regarded as the first person to demand complete independence for India in 1921 at the Ahmedabad Session of the Indian National Congress. He was deeply impressed by the Russian revolution and carried its imprint on all his writings. A deeply religious man (he went on the Hajj 13 times), he saw no contradiction between being pan-Islamist, nationalist and a Communist Muslim. Mohani served as the Chairman of the Reception Committee at the founding of the Communist Party of India on 25th December 1925 and was a member of the party until 1927. Along with Azad Sobhani, he set up the Muslim Independent Party in July 1932 but later joined the Muslim league in 1937. Mohani remained in India after the partition as an independent-minded, liberal, devout Muslim. He first recorded in prose and later used as a rallying cry at a labour rally in Calcutta in 1928 the slogan Inquilab Zindabad! He edited the journal Urdu-eMoalla.

His famous poem on the reforms bills named as 'Montagu Reforms' starts with:

How replete with deception it is

This scheme of reform by Montagu

In the whole wide world it is known

That these aspects of the Constitution spell

Complete control over legislation

Force over actions, power over money

When there's not even a whiff of these

In this flower of reform.

This poem is a scathing attack on the so-called reforms which were mere kaagaz ka phool ('paper flowers') with no khushboo ('fragrance') even for namesake. The poem ends with a fervent plea that the people of Hindu should not be taken in by the sorcery of reforms:

If you couldn't take anything from them now

You're not likely to get anything at all.

Another rebellious writer of India was Josh Malihabadi (1898-1982) was born in a feudal family of Awadh. He always had rebellious views and wrote fiery but extravagantly lyrical poetry. While his first collection Rooh-e-Adab (1921), established him as a poet of youth and vigour, later years saw him become the undisputed Sahir-e- Inqilab or the poet of revolt and rebellion. Devoted to the cause of nationalism, Josh drew his readers towards the heady idea of freedom like no else hitherto had, using a blend of suggestion and forthrightness, seduction and sermonizing, extravagance and subtlety. Producing a number of collections of poetry, each more lyrical, more rousing, more stirring, Josh's oeuvre has piles upon piles of colourful images tumbling out of a kaleidoscope, dazzling his readers with their astonishing and seemingly inexhaustible variety.

His famous poem 'Shikast-e Zindaan ka Khwaab' ('The Dream of a Defeated Prison') starts with:

How the prison of Hind is trembling and the cries of God's Greatness are echoing

Perhaps some prisoners have got fed up and breaking their chains

The prisoners have gathered beneath the walls of the prisons with

A storm of thunder in their beasts and swords reflected in their eyes...

Josh Malihabadi acquired his moniker shair-einquilab or the revolutionary poet during this period. He talks with vim and vigour of the revolution that is nigh, a revolution that will shake the foundation of the British Empire.

The poem ends with a warning to the cruelty of the British Empire:

Beware, for that prison is resounding, pounce for that prisoner has escaped

Rise for those walls have fallen, run for those chains have broken.

Akbar Allahabadi (1846- 1921) was employed as a naib tahsildar, he quickly rose to first become a lawyer and then munsif, sessions judge, district judge and finally Khan Bahadur in 1894. After retirement, he devoted himself to poetry and a passionate engagement with the political and social issues of his age. Using the metaphor of 
Budhhu Miyan for the Indian Muslim (a confused, none too -smart sort of little fellow) in some places and Shaikh (a pompous English stooge, occasionally a parody of Sir Syed) elsewhere, Akbar poetry relfects all the contradictions of his age.

Allahabadi's long poem 'Kulliyat' is a critique of colonial rule in India and similar with the notion of Rabindranath Tagore. Tagore's view in 'The Roots of War' published in the journal Sobuj Patra is that the First World War is a battle between soldiers and merchants, between Kshatriya and Vaishyas. Theorising through the tropes of the Indian caste system and Mahabharata's Kurukshetra war, he links European mercantile interests with the expansion of the Empire in Asia and Africa. Allahabadi too voices with the same strain:

Real goods are those that are made in Europe

Real matter is that which is printed in the Pioneer

Though Europe has great capability to do war

Greater still is her power to do business

They cannot install a canon everywhere

But the soap made by Pears is everywhere.

A famous poet, thinker and visionary Muhammad Iqbal (1877 -1938) drew on the best resources of a liberal Western education, having graduated from the prestigious Government College, Lahore, then studying philosophy at Trinity College, Cambridge in Heidelberg and Munich in Germany and also Bar-at-law. Although he returned to teach for two years before quitting government service altogether, he earned no more than a modest livelihood as a lawyer and choose to devote himself entirely to reading and writing. Given his trenchant criticism of the imperial government, he surprisingly enough accepted a knighthood in 1922. In 1927 he was elected to the Punjab Legislative Council. In 1931, he attended the Round Table Conference in London as a member of the Indian Muslim delegation led by the Aga Khan. His prodigious poetry is contained in diverse collections.

The great and famous poet Iqbal, who is at his most active and most powerful during these years of Great War warns Indians to be careful, to heed the signs in his poem 'Tasveer-e Dard' ('A Picture of Pain'):

The sight of you makes me cry, O Hindustan

For your tale is most admonishing among all tales

The tears you have given are all you have bequeathed

The pen of destiny has placed me among those who mourn you...
The poem ends with an appeal to seize what's happening and the ever-true facts that the history of the soldiers will not be remembered in the pages of history:

Look, watch what is happening, see what is about to happen

There's nothing to be gained from the stories of past glories

If you still don't understand you will be erased o people of Hindustan

Even your tales will be removed from the annals of the world history.

Ahmaq Phaphoondvi Aka Muhammad Mustafa Khan Maddah (1895 - 1957) was born in Phaphoond in the Etawah district of Uttar Pradesh. His real name was hakim Muhammad Mustafa Khan 'Maddah'. Phaphoondvi studied in Tibbiya college in Delhi but before he could set up his practice after completing his education in medicine he joined the non cooperation movement against British rule. He took an active part in India's freedom movement for which he suffered imprisonment. Phaphoondvi is considered to be one of the most important poets of humour and satire, choosing social, political and cultural issues as objects of his satire. He also wrote ghazals and nazms, many of which are patriotic and raise the voice of protest against British domination. Apart from writing poetry, Phaphoondvi also compiled in Urdu Hindi dictionary which was published by the Uttar Pradesh Government as Urdu Hindi Shabd Kosh.

In a satirical tone, he admires the sharpness of the British brain in 'Angrezi Zehnki Tezi', while he is actually warning the readers of the perils of being divided. The poem starts with:

Look at the turmoil and bloodshed among our people

The cleverness of the English mind is used up in all such schemes

This murder 'n mayhem, wars 'n battles, cruelties 'n malice

The country's garden is barren, with nothing but dust and desolation.

Another famous Indian poet Zafar Ali Khan (1873 - 1956) was a freedom fighter, a translator, political activist and journalist and the editor of the influential newspaper Zamindar which played an important role in spreading awareness about the evils of colonial rule among Indians. Khan is generally considered to be the father of Urdu journalism. Clearly opposed to Mahatma Gandhi's policy of non-violence, he believed in direct confrontation with the British and ardent supporter of the Khilafat 
movement, he also had to serve a prison term of five years for his role in the freedom movement. For Khan, poetry was a mode of socio political resistance. Most of what he wrote represents contemporary history in literary terms. His collection of poems include Biharistan, Nigaristan and Chamanistan.

His poem 'Azadi ka Bigui' ('The Bugle of Freedom') starts with a warning tone:

The world has changed, so must you

Beware, for the time past won't return

But the heat and the flow of your blood must be so

That it should melt even a mould of ice.

The poem continues:

Holding aloft the flag of complete freedom

Go forth playing the bugle of belief,

Some crumbs have fallen from the table of Britannia

O Toadies, go crawling on your bellies to pick them.

While warning his fellow Indians to change with the changing winds that are blowing across the country as the war drags to an end, he's also pointing our attention to the Toadies, a dreaded word for subservient Indians who will gladly accept any crumbs by way of reforms.

A prolific Urdu poet, playwright and dramatist Agha Hashar Kashmiri (1879 -1935) went on to attain great fame after several of his plays were turned into films. The most notable among them are Yahudi ki Ladki, Rustom-o Sohrab and Laila Majnu. He is also credited with translating a number of Shakespeare's plays for Hindustani and audiences such as Safed Khoon (White Blood) based on King Lear and Khwab-e Hasti (A dream of Existence) loosely based on Macbeth.

In the poem called 'Shukriya Europe' ('Thanks for Europe'), Harshar Kashmiri thanks in a sarcastic ode to Europe for turning the world into a matamkhana ('mourning chamber') and for having successfully transformed the east into an example of hell.

The highest rate of recruitment was in Punjab which had contributed 360,000 recruits to the First World War battlefield. What do survive, are folksongs about the war and recruitment. The distinguished Punjabi poet Amarjit Chandan recovered those folk songs extracts and published in 'How they suffered: World War One and its Impacts on Punjabis. These folk songs have been translated by Chandan and Amin Mughal. Chandan recited the song in Punjabi at the 2009 conference in London on 'South Asian Experiences of World Wars'.

Amarjit Chandan's collection of Punjabi folk songs is a subterranean stream of memory that needs to be go through to understand their experiences during WW1. These qissa kahanis, oral narratives, folk songs and ditties recover the reminiscences of forgotten past and retrieve lost voices. Their stories of experience in the battlefield, both forced and voluntary, provide important aspects of social forces that are overlooked by historians. While there is hardly any oral culture and folk songs on the Partition of 1947, there is rich crop of folksongs on the two World Wars. The themes of the oral culture vary from bereavement for the death of near ones to the biraha or separation of the women from their husbands who were forced to join the army.

In conclusion, it can be said that in the poems and oral songs language is the medium of expression to voice the oppression and the inhuman condition of the British Indian soldiers under the rule of British raj. This is the literature of resistance to the Eurocentric attitude to culture, history and language. Literature consolidates their culture identity. Their cultural identity and mental makeup have been fossilized through the literature they produced. This is an alienated class. They are the harbinger of resistance. The national heritage of India came alive through the poetry of oppression. The Indian poets aligned themselves with the struggles of Indian soldiers during the First World War.

The oral narrative as well as 'war poems' written by poets of undivided India shared their varied experiences of battlefield and how India contributed their sons in foreign land forcibly or voluntarily have been neglected by the modern historians. These stories have become the mouthpiece of the subaltern voices. Their voices were suppressed and they were not allowed to speak against the 'master' British army for their inhuman torture. It is clear from such rich oral narratives and poems that the subaltern can speak but can we, the modern men, hear their voices? After hundred years of First World War, the Indian contribution to the First World War still remains tardy. Such study of Indian responses to war will spur greater interest in this hitherto neglected aspect of the history of the Indian peoples. There is homogeneous literature from undivided India as the experience of the South Asian troops. Such nuanced vitality and diversity of literary production is alone an illuminating example of rich socioculture heritage of Indian cultural tradition.

\section{REFERENCES}

[1] Abrams, M. H., and Geoffrey G.H. (2009). Handbook of Literary Terms. Cengage Learning. 
[2] Ashcroft, B., Griffiths, G., Tiffin, H. (2007). Post-Colonial Studies: the Key Concepts. Routledge

[3] Basu, S. (2016). For King and Another Country: Indian Soldiers on the Western Front, 1914-18. Bloomsbury.

[4] Das, Santanu. (2014). "Indians at Home, Mesopotamia and France, 1914- 1918: Towards an Intimate History." Race, Empire and First World War Writing. Cambridge: Cambridge UP.

[5] Das, Santanu. (2020). Literature (India) in: 1914-1918online. International Encyclopedia of the

[6] First World War. Freie Universität Berlin, Berlin. DOI: 10.15463/ie1418.11465.

[7] Keene, Jennifer D., and Michael S. Neiberg. (2011). "Imperialism, Nationalism and the First World War in India." Finding Common Ground: New Directions in First World War Studies. Leiden: Brill.

[8] Jalil, Rakhshanda. (2019). The Great War: Indian Writings on the First World War. Bloomsbury.

[9] Leitch, Vincent B., William E. C., Laurie A. Finke, John M., T. Denean Sharpley-Whiting, and Jeffrey J. W. (2018). "Frantz Fanon." The Norton Anthology of Theory and Criticism. New York: W.W. Norton.

[10] Loomba, Ania. (2015). Colonialism/Postcolonialism. Routledge, Taylor \& Francis Group.

[11] Singha, Radhika. (2020). The Coolie's GREAT War: Indian Labour in a Global Conflict, 1914-1921. HarperCollins Publishers India.

[12] Wikipedia contributors. (2021,). Hasrat Mohani. In Wikipedia, The Free Encyclopedia. Retrieved 10:19, November 11, 2021, from https://en.wikipedia.org/w/index.php?title=Hasrat_Mohani\& $\underline{\text { oldid }=1052889548}$

[13] Wikipedia contributors. (2021, October 15). Subaltern (postcolonialism). In Wikipedia, The Free Encyclopedia. Retrieved 13:13, November 12, 2021, from https://en.wikipedia.org/w/index.php?title=Subaltern_(postc olonialism)\&oldid=1050124601 